\title{
Kultura chłopska w optyce prasy społeczno-kulturalnej lat 1944- 1948. „Warszawa” i dyskusje nad modelem kultury powojennej Polski
}

Bożena Karwowska 


\section{Kultura chłopska w optyce prasy społeczno-kulturalnej lat 1944-1948. "Warszawa" i dyskusje nad modelem kultury powojennej Polski}

Bożena Karwowska

TEKSTY DRUGIE 2017, NR 6, S. 209-220

DOI: $10.18318 /$ td.2017.6.12

Dowojenne dyskusje prasowe odnoszące się do sytuacji kultury w powojennej Polsce odbywały się w kontekście ówczesnej sytuacji politycznej, a niekiedy wręcz weń wpisywały. W praktyce, co zauważali sami publicyści, zagadnienia literatury, sztuki i kultury w czasopismach kulturalno-literackich pojawiały się jedynie na marginesach, podczas gdy główne szpalty prasowe zajmowały wypowiedzi na temat sytuacji politycznej i społecznej. Ta bowiem, zdaniem krytyków, miała podstawowe znaczenie dla kształtu literatury i sztuki odradzającego się państwa. To nie prądy kulturalne i idee wyrażane przez twórców i artystów decydować miały o kształcie społeczeństwa, ale polityka społeczna miała decydować o kształcie kultury, która z kolei miała pomagać w budowaniu świadomości politycznej powojennych Polaków. A sytuacja powojenna społeczeństwa, która stanowiła punkt wyjścia prasowych dyskusji, opisywana była w ramach dość szybko ustalonych stereotypowych uogólnień i klisz.

Przypominając pokrótce podstawowe zagadnienia i punkty wyjścia, posłużę się tu obserwacjami Jana
Bożena Karwowska associate professor na Wydziale Studiów Europy Środkowej, Wschodniej i Północnej, University of British Columbia w Vancouver. Zainteresowania badawcze: czytelnik i recepcja literacka, teorie feministyczne oraz literacka reprezentacja Zagłady. Ostatnia książka: Kobieta - Historia Literatura (2016). Od 2014 roku we współpracy z Muzeum Auschwitz-Birkenau prowadzi seminarium Świadectwa Zagłady, którego efektem jest tom The More I Know, The Less I Understand (współred. z Anją Nowak). 
Nepomucena Millera, który w 1946 roku pisał: „W wyniku wojny szósta część ludności przestała dla państwa istnieć, piąta część pozostałej uległa wyniszczeniu, ocalała reszta musiała zmienić częściowo teren swego zamieszkania, przesunąć się na zachód, na ziemie wydarte sobie w zaraniu swoich dziejów”". Jan Szczawiej, redaktor naczelny literacko-kulturalno-społecznej „efemerydy" prasowej lat 1946-1950 „Warszawa”, podobnie jak publikujący w piśmie Miller skrótowo zauważa: „Trzecia część narodu wymordowana - to nie wszystko co miało nas spotkać". Trudno tu ocenić, czy w cytowanej liczbie zabitych mieścili się również polscy Żydzi, czy publicysta poprzez naród rozumiał wyłącznie tych, których niemieccy okupanci klasyfikowali jako ludność pochodzenia aryjskiego. Okupacyjną przeszłość Szczawiej traktuje dość zdawkowo, stawiając na najważniejszym miejscu obserwacje i pytania odnoszące się do zmiany granic kraju. W numerze 6 pisma, w artykule Ziemie Polskie na zawsze pisał:

Kiedy kazano nam zrezygnować w wyniku sytuacji międzynarodowej z części naszego terytorium państwowego na rzecz innego państwa sojuszniczego, podjęliśmy twardą, męską decyzję dania posłuchu tym sojuszniczym żądaniom i tym sojuszniczym radom, bo tego wymagał w tamtej chwili interes narodów sprzymierzonych i przyszłość wspólnie przez nas prowadzonej walki z Niemcami.

Przyjęliśmy też jako rzecz, która nie będzie już ulegała najmniejszej dyskusji, powrót do Polski prastarych ziem polskich na Zachodzie, gnębionych w jarzmie niemieckim i bezskutecznie germanizowanych przez kilka stuleci. $^{2}$

Przesunięcie granic i "powrót” na starodawne ziemie to temat powracający często i przez wiele lat na łamach prasy, stanowiący swoistą ramę polityczno-społeczną dyskusji dotyczących kształtu kultury powojennej Polski. Z dzisiejszej perspektywy dość trudno odpowiedzieć na pytanie, na ile owa zmiana granic oraz stosunkowo silniejsze prosowieckie sympatie środowisk żydowskich na terenach, z których Polska „zrezygnowała”, sprawiły, że problematyka stosunków polsko-żydowskich w okresie okupacji, szczególnie w środowiskach wiejskich na wschodnich terenach kraju, została nie tylko

1 J.N. Miller Obrona konwencjonalizmu i szablonu, "Warszawa” 1946 nr 2, s. 2.

2 J. Szczawiej Ziemie Polskie na zawsze, "Warszawa" 1946 nr 6, s. 3. 
zmarginalizowana, ale w praktyce całkowicie usunięta poza zakres zainteresowania krytyków i czytelników pism społeczno-kulturalnych. Niemniej jednak brak ogólniejszej refleksji dotyczącej sytuacji Żydów ukrywających się na wsiach w okresie okupacji oraz stosunku chłopów do żydowskich sąsiadów jest dość wyraźny i znaczący. Pojedyncze głosy literackie, jak np. opowiadanie Przy torze kolejowym z tomu Medaliony Zofii Nałkowskiej, nie były w stanie wypełnić owej pustki. W sumie główne tematy krytyków to podkreślanie ogromu zniszczeń wojenno-okupacyjnych i przemiany polityczne w kraju, a ton ich wypowiedziom zaczyna nadawać dyskurs rodzącej się właśnie zimnej wojny. Pominięcie problematyki zagłady Żydów w dyskusjach i polemikach prasowych w Polsce nie odbiega zresztą od światowych standardów tamtych czasów. Kulturowe uwarunkowania powojennego amerykańskiego dyskursu wyzwoleńczego skupiającego się na heroicznym wyzwalaniu Niemców od nazistów sprawiły, że Żydów i ich Zagładę marginalizowano w anglojęzycznych wypowiedziach. Blok wschodni także budował swój własny wyzwoleńczy dyskurs, który opiewał heroizm Armii Radzieckiej i jej wschodnioeuropejskich sojuszników, a nie zagładę Żydów. W dyskusjach i wypowiedziach prasowych odwołanie do przeszłości (włączając w to wszystko, co wydarzyło się na terenach Polski w okresie okupacji) sprowadzało się często do stereotypowego i emfatycznego stwierdzenia: „Wyszliśmy z głuszy okupacyjnej nocy na światło dnia"3.

„Warszawę", pismo wydawane w latach 1946-1950, nieprzypadkowo wybrałam jako źródło, z którego głównie czerpałam przykłady do niniejszych rozważań. Choć Jerzy Myśliński określa ją jako periodyk o niewielkim znaczeniu dla procesów kulturowych wczesnych lat powojennych, dla niniejszych rozważań pismo to jest istotne, gdyż postrzegane było jako opozycyjne w stosunku do obozu władzy" . Warto zauważyć, że nieistotność „Warszawy” polegała na jej częściowej przynajmniej wtórności i uległości w stosunku do coraz wyraźniej narzucanych przez władze modeli oraz na jej ograniczonym oddźwięku w środowiskach czytelniczych. Jej opozycyjność natomiast nie była wymierzona przeciw władzy, ale wiązała się z próbą zaproponowania alternatywnego (choć budowanego w ramach tej samej odgórnie promowanej ideologii) modelu kultury. Ponadto, tematyka chłopów i kultury ludowej pojawiała się w „Warszawie” zaskakująco często, choć w odróżnieniu od

3 J.N. Miller O wagę słowa, "Warszawa” 1946 nr 6, s. 1.

4 J. Myśliński Lata 1944-48, w: Czasopisma kulturalne i społeczne w PRL, Wydawnictwo IBL PAN, Warszawa 2012. 
„Wsi” (której ton ideowy nadawał Adam Ważyk), pismo nie było skierowane do inteligencji wiejskiej, lecz do szerszych kręgów wykształconych i wyrobionych czytelniczo odbiorców. Co także istotne, być może właśnie dzięki swojej wtórności publicystyka „Warszawy” stanowi swoiste, czasem wręcz krzywe, zwierciadło dyskusji środowisk zajmujących się literaturą i kulturą. Pokazuje ich język i zakres zainteresowań, a także najistotniejsze elementy polityki społecznej i roli, jaką w budowie powojennego społeczeństwa miała odegrać literatura i kultura, szczególnie ta tworzona przez klasy mające objąć przywódczą rolę w nowym państwie, czyli robotników i chłopów. Ograniczony wpływ dyskusji i tekstów zamieszczanych w „Warszawie” pozwala na spojrzenie na nie jako na świadectwo (nikłości) znaczenia środowisk ludowych (czy wiejskich) w procesach kształtowania kultury PRL-u. Jednocześnie stanowią one przykład prób - podejmowanych przez inteligencję wywodzącą się ze środowisk wiejskich oraz tę o korzeniach socjalistycznych (zdecydowanie różnych od komunistycznych) - wykorzystania kultury ludowej jako materiału dla tworzącej się literatury i kultury powojennego społeczeństwa polskiego. Szczególnie istotne były w tym kontekście próby pokazania jej jako alternatywnej dla modelu kultury środowisk robotniczych.

Na tym być może właśnie, a nie na wyraźnie akcentowanej przez Jana Szczawieja w relacji prasowej nieobecności blisko związanych z pismem Dąbrowskiej, Boguszewskiej i Millera na trzecim zjeździe literatów - opierała się podkreślana przez Myślińskiego opinia o opozycyjności pisma. Związani z „Warszawą” publicyści wyraźnie przeciwstawiali się próbom politycznego nacisku na oparcie kultury powstającego państwa wyłącznie na kulturalnym interesie klasy robotniczej, posługując się w tym celu pokazywaniem i uwydatnianiem wartości wyrastających z wiejskich tradycji kultury ludowej jako modelu alternatywnego lub współtowarzyszącego kulturze robotniczej. Z drugiej zaś strony nie zgadzali się z promowaną m.in. przez „Wieś” krytyką twórczości „ziemiańskiej” i powszechnym wśród komunizujących krytyków patrzeniem na środowiska wiejskie przede wszystkim poprzez model (ich) klasowego rozwarstwienia. Krytyka opisów wsi ignorujących ową klasowość pojawiła się w tekstach publikowanych w „Warszawie” dopiero w ostatnich numerach pisma i, co niezwykle ważne, nie była próbą zastąpienia pojęcia ludu przez terminologię związaną z marksistowskim dyskursem klasowym.

Pomimo powszechnego i częstego podkreślania w powojennej prasie ogromu strat wojennych i okupacyjnych tylko uważny czytelnik zauważy, że wypowiedzi na temat strat osobowych dotyczą przede wszystkim, o ile nie wyłącznie, inteligencji (często wymieniani są w tym kontekście nauczyciele), 
a zniszczenia kraju prasa opisywała, głównie mówiąc o zniszczeniach gospodarki przemysłowej. Wieś wydaje się ze zniszczeń wojennych i okupacyjnych wychodzić stosunkowo łagodnie (tak przynajmniej wynika z artykułów i polemik), w dużej mierze dzięki pominięciu związanej z wsią problematyki w opisach dewastacji ekonomicznej kraju. Dodajmy tu, że choć np. Jan Nepomucen Miller rozpoczyna często swoje prasowe polemiki od wyliczania przemian, jakie nastąpiły w powojennej Polsce, zadziwiać może nieomal całkowite niezauważanie wojny i okupacji jako czasów kulturotwórczych lub mających znaczenie dla kształtu kultury powojennego kraju i ograniczanie ich wpływu do różnorodnych strat osobowych i gospodarczych. Powojenne przemiany w publicystycznym języku zawsze oznaczają porównanie z okresem międzywojennym, a ich głównym (o ile nie jedynym) motorem jest prokomunistyczna ideologia nowej władzy.

Cechę charakterystyczną wypowiedzi publicystów w tamtych latach stanowi ich wyraźnie oceniający i wartościujący ton. Wynika to z tego, jak widzieli oni swoją rolę, która nie ograniczała się do upowszechniania kultury, ale obejmowała także konieczność wyboru i oceny. „Jeśli [...] mamy szerzyć czy rozpowszechniać kulturę i sztukę, wychodząc z założenia jej społecznej wartości, musimy się zdecydować, jaka forma czy postać tej sztuki godna jest szerzenia", pisze Miller ${ }^{5}$. Innymi słowy - ponieważ podstawowym zadaniem sztuki jest społeczne oddziaływanie, zadaniem krytyka i działacza kultury ma być przede wszystkim ocena społecznej wartości dzieła, a dopiero później refleksja odnośnie do aspektów artystycznych utworu wartego rozpowszechniania. Sztuka miała przenosić treści i ideały odpowiadające modelowi społecznemu powojennej Polski, choć Miller wiązał owe ideały także z określoną, choć niezdefiniowaną bliżej formą (lub postacią). Język, jakim posługiwali się krytycy, jest w odniesieniu do formy artystycznej wyjątkowo niejasny, choć dość wyraźnie zarysowane zostały kontury tego, co w odrodzonym kraju miało być nieakceptowalne, także pod względem formy artystycznej. Początkowo skupiano się więc na krytyce tego, co naganne, a z czasem okazało się, że to właśnie formy zapożyczone z twórczości folklorystycznej najlepiej odpowiadają upolitycznionym wymaganiom.

Powojenne zmiany społeczno-polityczne i ciągłe odniesienia do Polski międzywojennej sprawiły, że początkowo główny atak publicystów skierowany został na przedwojenne środowiska określane w latach 40. jako „pseudointeligenckie”. Chodziło przede wszystkim o środowiska mieszczańskie

5 J.N. Miller Wielopostaciowość sztuki i kultury, "Warszawa” 1946 nr 3, s. 3. 
i ziemiańskie propagujące, zdaniem powojennych publicystów, kosmopolityczne ideały, wyrażone równie kosmopolityczną formą i dalekie od wartości wyznawanych przez robotników i chłopów. A to właśnie w imieniu tych ostatnich postulowano powojenne zmiany, i to ich kultura stanowić miała model dla powstającego po wojnie państwa. Nie chodziło zresztą tylko o treści, gdyż kultura ludu miała stanowić także wzór „formy” czy „postaci” godnej rozpowszechniania.

Jednak pomimo powszechnego stawiania w stereotypowych sformułowaniach politycznych robotników przed chłopami, nie pojawiała się w publicystyce „Warszawy” formuła twórczości robotniczej, a tylko pisarstwa reprezentującego wartości środowisk robotniczych. To nadal bliżej nieokreśleni klasowo pisarze, a nie robotnicy byli opisywanymi czy cytowanymi twórcami literatury. Ubolewano przy tym, że punkt widzenia chłopa nie był w (oficjalnej czy też „wysokiej”) literaturze reprezentowany. Miller zauważał, że „O ile Broniewski i Szymański mogli sobie poniekąd rościć pretensje, że wyrażają również nastawienie psychiczne klasy robotniczej, o tyle stwierdzić należy, że chłopi mniej jasny i skrystalizowany znaleźli wyraz swej postawy w powieści o tematyce zaczerpniętej z życia chłopskiego (Kowalski, Kruczkowski, Wasilewska). Świadomość chłopską w tej powieści budowano zbyt widomie na wzorcach świadomości klasowej robotnika"6. Posługując się pojęciowością postkolonialną i niejako prześmiewczo, można byłoby więc powiedzieć, że chłopi, którzy przed wojną podlegali naciskom środowisk ziemiańskich i inteligenckich, także w powojennej Polsce mieli zostać pozbawieni prawa do własnej tożsamości, gdyż ich kultura miała zostać podporządkowana wartościom kultury robotniczej. Tym bardziej istotny był więc fakt, że niektóre środowiska intelektualne (a szczególnie krytycy o korzeniach wiejskich) argumentowały, że kultura ludowa (lub kultura chłopska) prezentuje zarówno społeczną wartość, jak i formę odpowiednią dla powojennych odbiorców, a zatem stanowić mogła model alternatywny dla kultury robotniczej.

Dobrym przykładem upolitycznionego podejścia krytycznego jest artykuł Jana Aleksandra Króla w tygodniku „Wieś”, poświęcony opisowi wsi przez Jana Kochanowskiego, który - jak inni pisarze zachwycający się wsią i jej wartościami - korzystał z pracy chłopów, a właściwie z wyzysku feudalnej wsi. Za Kochanowskim ujęła się w „Warszawie” Maria Dąbrowska ${ }^{7}$, której tekst Obrona Kochanowskiego jest wyraźną odpowiedzią na napaść w tygodniku

6 J.N. Miller Obrona konwencjonalizmu i szablonu „"Warszawa” 1946 nr 2, s. 2.

7 M. Dąbrowska Obrona Kochanowskiego, "Warszawa” 1946 nr 7, s. 1. 
„Wieś". Podczas gdy Król argumentował, że ziemianie uciskający chłopów jednocześnie głosili w poezji ideały humanistyczne, Dąbrowska twierdziła, że źródłem inspiracji Kochanowskiego była nie tyle wieś, ile poezja Horacego. Jeśli zaś chodzi o aspekty klasowe, to pisarka stwierdzała także, że Kochanowski nie „tuczył się pracą chłopów”, ale zaczynał tworzyć i przez wiele lat pisał jako ubogi student. Jako jedna z nielicznych ciekawie opisuje Dąbrowska wartości ludowej literatury, zwracając przede wszystkim uwagę na język poetycki twórcy Trenów. Dąbrowska zauważa, że język Kochanowskiego nie jest językiem powszechnie krytykowanej XX-wiecznej inteligencji i mieszczaństwa, ale jest najbliższy językowi współczesnych chłopów, gdyż tylko ich polszczyzna zachowała w sobie piękno staropolskiego słownictwa i składni. Ponadto wartości, które zdaniem pisarki przenosi poezja Kochanowskiego, to piękno natury i krajobrazu, niejako stereotypowo pojawiające się w wielu opisach i uwagach odnoszących się do twórczości ludowej.

Przyjmujący rolę naczelnego wyraziciela opinii pisma "Warszawa” Jan $\mathrm{Ne}$ pomucen Miller nie negował głoszonej powszechnie w prasie przywódczej roli robotników, ale uważał za szkodliwe narzucanie im takiej samej roli, jaką, zgodnie z obowiązującym światopoglądem, odgrywali w społeczeństwie, również w sferze kultury. Zwierzchnia rola w społeczeństwie nie powinna, zdaniem krytyka, prowadzić do standaryzacji w tej dziedzinie. Zgodnie z przyjętą w środowisku opiniotwórczym frazeologią, Miller nie odwoływał się jednak w tym kontekście do tradycyjnej roli, jaką w tworzeniu dóbr kultury odgrywała inteligencja i warstwy artystyczne („skompromitowane” w oczach powstającego powojennego narodu), ale upominał się o udział chłopów i społeczności wiejskiej w tworzeniu kultury ogólnonarodowej. „Mimo przewodniczej i awangardowej roli proletariatu i jego świadomości klasowej w kształtowaniu się nowej kultury, pominięcie czy celowe niedowidzenia wkładu, jaki wnieść musi do zbiorowej kultury ludowej narodu wyzwolone z pęt obszarnictwa chłopstwo, jest rezygnacją z wzroku na rzecz węchu i dotyku"8, argumentował Miller. Zwraca też uwagę w jego wypowiedzi sformułowanie dotyczące „zbiorowej kultury ludowej”, mogące sugerować, że chodzi mu o kulturę nastawioną na masy raczej niż na elity. W tym aspekcie ciekawy argument przywołuje Paweł Hulka-Laskowski w tekście zatytułowanym Cywilizacje naskórkowe $e^{9}$ gdzie jako kulturę powierzchowną, naskórkową określa dorobek klas wyższych oraz kleru. On także jednak z rezerwą odnosi

8 J.N. Miller Wielopostaciowość sztuki i kultury.

9 P. Hulka-Laskowski Cywilizacje naskórkowe, „Warszawa” 1947 nr 3, s. 2. 
się do stawiania za jedyny pozytywny przykład i model kultury robotniczej. Jego zdaniem na przestrzeni dziejów podstawą społeczeństwa byli chłopi, niszczeni przez panów (przywołuje jako przykłady pańszczyznę i przywiązanie do ziemi, a także propinację), a dopiero potem pojawili się robotnicy, którzy tym samym są uciskani krócej. Z takiego rozumowania wynika, że lud to chłopi i robotnicy, a więc to oni są twórcami kultury ludowej.

Miller sprzeciwia się także powszechnemu podkreślaniu szeroko rozumianej dominacji miasta nad wsią. Wyraża niejednokrotnie swój negatywny stosunek do masowych mediów wprowadzających na wieś obce jej kulturowo modele. Zdaniem publicystów „Warszawy”, wystarczająco mocnym elementem ewokującym zmiany społeczne była reforma rolna, która pozwoliła wsi na odrodzenie jej własnej kultury oraz na wytworzenie tożsamości ludowej (a może powrót do niej?). „[C]hłop przestał być zbieraczem okruchów z pańskiego stołu, nabiera samowiedzy społecznej, poczucia własnej wartości, uświadamia sobie swą rolę sprawczą w życiu narodu", pisał Miller ${ }^{10}$.

Ale to przede wszystkim Kazimierz Czachowski, związany z wsią poprzez swoje zainteresowania i wieloletnią pracę, argumentował bardzo wyraźnie, że reforma rolna ma wpływ nie tylko na stosunki produkcji i układ społeczny, ale także na sztukę i na środowiska artystyczne. Jako jeden z niewielu (prawdopodobnie właśnie dzięki swoim bliskim związkom z wsią) podkreślał Czachowski wojenne wyniszczenie gospodarcze wsi, ale argumentował także, że w nowym ustroju wieś odrodzi się szybko, a więc możliwy będzie także jej rozwój kulturalny. Krytyk nie przekreślał przy tym kulturotwórczej roli środowisk artystycznych, ale zwracał uwagę na konieczność przybliżenia wsi literatom i twórcom kultury, zauważając, że reforma rolna stworzyła na wsiach szkoły, ale także ośrodki wypoczynkowo-twórcze dla ludzi kultury ${ }^{11}$.

Trudno jest jednak jednoznacznie określić, kim dla Millera i Czachowskiego oraz pozostałych publicystów byli chłopi czy środowiska chłopskie (lub wiejskie), a łatwo zauważyć bałagan panujący w nazewnictwie chłopsko-wiejsko-ludowej kultury i niedomówienia pozwalające na dość dowolne manipulacje terminologiczne. Stąd być może w publicystycznych wypowiedziach doszukać się można analogii do sowieckiego modelu pojęcia folkloru i ludowości, w języku rosyjskim dosłownie powiązanego z pojęciem narodu i narodowości. Trudno odpowiedzieć jednoznacznie na pytanie, czy narodnyj artist to po polsku artysta ludowy czy też narodowy. W modelu radzieckim,

$10 \quad$ J.N. Miller Wielopostaciowość sztuki i kultury.

11 K. Czachowski Sztuka a ustrój społeczny, „Warszawa” 1946 nr 3, s. 4. 
który prowadzi do upolitycznionych nadużyć, sprzyja takiej zbitce językowej nakładanie się na siebie pojęć - rosyjskie narod (szczególnie w dyskursach porewolucyjnych) oznaczać mogło zarówno to, co w innych językach określa pojęcie „lud”, jak i to, co określa pojęcie „naród”. Oczywiście pokrywanie się terminologii wiązało się z modelem społeczeństwa, bardzo różniącym się w przed-i porewolucyjnej Rosji od burżuazyjnych społeczeństw tak zwanego Zachodu. W analogicznym do rozpatrywanego tu okresu powojennego w Polsce, folkloryści w ZSRR (a szczególnie Piotr Bogatyriew i pozostali autorzy zbiorowej pracy Russkoje narodnoje poeticzeskoje tworczestwo ${ }^{12}$ ) wprowadzili kategorie "ludowego" i „nieludowego” w twórczości ludu, a także definicje folkloru i kultury ludowej oparte na marksistowskich klasowych podejściach do społeczeństwa. Modelem dla kultury i literatury bezklasowego społeczeństwa, do którego stworzenia dążyły władze ZSRR, miała być właśnie kultura ludowa rozumiana w bardzo specyficzny sposób, czyli jako ta część kultury ludu, która odzwierciedla historyczny interes klas pracujących. W tym kontekście niepokojąco brzmi fraza „Kultura, która zasługuje na miano ludowej" - a takiego określenia użył Jan Nepomucen Miller w 3. numerze „Warszawy”13 (z 1946 roku).

Obraz tego, czym miała być literatura chłopska, najlepiej pokazać powinny recenzje nielicznych powieści wiejskich powstałych lub wydanych w pierwszych latach powojennych. Refleksję nad nimi utrudnia jednak nie tylko ich niewielka liczba, ale także brak możliwości dotarcia do większości recenzowanych tekstów literackich wydanych przez niszowe i dziś już nieistniejące wydawnictwa. Ponadto mieszają się w nich pojęcia ludowości, wiejskości i chłopskości, a zbyt mała liczba tekstów w połączeniu z krótkim okresem istnienia pisma nie pozwoliły recenzentom na wypracowanie spójnego krytycznego języka.

Na zakończenie warto przywołać głos Mariana Piechala z 1949 roku, kiedy „ludowość" wydaje się nie być już związana z „chłopskością,., „Jeżeli w nowej odrodzonej Polsce masy chłopskie i robotnicze stać było na to, aby przy pomocy własnych rąk zbudować mocne zręby nowego ustroju, stać je i na to, aby własnymi także ustami wypowiedzieć to, co myślą ich głowy i odczuwają ich serca. Zadaniem narodowej, prawdziwie twórczej krytyki i publicystyki jest wołać o te nowe usta i notować skrzętnie każdy głos, który z nich wychodzi,

12 P. Bogatyriew (red.) Russkoje narodnoje poeticzeskoje tworczestwo, Izdatielstwo Akadiemii Nauk SSSR, Moskwa 1954.

13 J.N. Miller Wielopostaciowość sztuki i kultury. 
odcyfrowywać jego nowe znaczenie, nowy sens i nową prawdę"14. Wzorem epopei chłopskiej jest dla Piechala Cichy Don Szołochowa, wzorem epopei miasta - twórczość Maksyma Gorkiego. Stanowią one wzór utworów ludowych pod względem treści, która pod koniec lat 40. wyraźnie została już odgraniczona od pytania o formę artystyczną. W tym samym tonie Piechal przedstawił swoje refleksje na temat ludowości poezji Mickiewicza.

Dyskusje te, podobnie jak i działalność pisma, kończy rok 1950. W przemówieniu do literatów z 18 lutego 1950, zatytułowanym „Rola i zadania pisarza socjalistycznego"15, Jakub Berman podkreśla klasowe rozwarstwienie wsi, a zatem problematykę ludową zastępuje całkowicie terminologia klasowa, która zamyka rozważania nad rzeczywistością wsi i jej mieszkańców na wiele następnych lat. Próby pokazania twórczości chłopskiej, wiejskiej, ludowej jako modelu dla kultury wczesnych lat PRL-u nie przyniosły rezultatów. Kultura chłopów i środowisk wiejskich nie stała się modelem konkurencyjnym (lub alternatywnym) dla wzoru dorobku robotników. Dotyczące tego dyskusje usunęły jednak całkowicie z pola zainteresowania krytyków i publicystów problematykę zniszczeń materialnych i kulturowych (oraz moralnych), jakie na wsi spowodowały okupacje lat 1939-1945. Kultura wsi pokazywana była jedynie jako model wart wykorzystania i naśladowania, a chłopi jako nosiciele wartości, na których opierać się miało nowe państwo polskie. W tym kontekście raczej oczywiste stało się pomijanie milczeniem ciemnych stron okupacyjnych zachowań chłopów w stosunku do ich dawnych żydowskich sąsiadów. Zbierane w tamtych latach przez Centralną Żydowską Komisję Historyczną relacje Żydów ocalałych niejednokrotnie wśród polskich chłopów, które stanowić mogły znakomity punkt wyjścia do dyskusji nad wpływem okupacji niemieckiej na moralno-etyczne aspekty kultury polskiej wsi, nie mogły w kontekście walki politycznej w powojennej Polsce zainteresować publicystów.

Pomimo wysiłków grupy skupionej wokół „Warszawy”, dla odbudowującego i przebudowującego się kraju kultura ludowa wsi okazała się zbyt tradycyjna i zastąpiona została „unowocześnioną" wersją lepiej odpowiadającą klasowym interesom powstającego społeczeństwa. Znakomity przykład owych substytucji stanowi piękna ludowa piosenka (śpiewana w późniejszych latach w oryginalnej wersji przez Państwowy Zespół Pieśni i Tańca „Mazowsze”) Cyraneczka nie ptak, która w wersji Tadeusza Sygietyńskiego i zespołu „Warszawa”

14 M. Piechal O społecznym sensie powojennej literatury, "Warszawa” $1948 \mathrm{nr}$ 6, s. 4.

15 Zob. .. Berman Rola i zadania pisarza socjalistycznego (z przemówienia wygłoszonego na konferencji literatów), "Odrodzenie" 1950 nr 9, s. 1-2. 
w filmie Spotkanie na Mariensztacie z 1953 roku zaprezentowana została w następującym kształcie:

Cyraneczka - nie ptak

Dziewczyna - nie ludzie...

- Po co dogadujesz?

Przecie mnie miłujesz.

- Po co dogadujesz?

Przecie mnie miłujesz.

Ojej - nie śpiwaj tak, bo śpiwasz na opak.

Jadą maszyny

na nich dziewczyny

a każda jako chłopak.

Jadą maszyny

na nich dziewczyny

a każda jako chłopak.

Cyraneczka - nie ptak

Dziewczyna - nie ludzie...

A mrygnę na niego,

zaraz za mną pójdzie.

Dziewczyna nie ludzie?

A popatrzcie ludzie

jak na traktorze

jadzie i orze,

a bo właśnie, że ludzie!

Jak na traktorze

jadzie i orze,

bo dziewczyna - to ludzie!

Zanim uprzemysłowienie zmieniło obraz polskiej wsi, zmieniło obraz folkloru i zamieniło dziewczęce uczucia na pracę traktorzystki. Nowe, młode pokolenie nastawione było na postęp i awans społeczny, w narodowo jednolitej i praktycznie pozbawionej Żydów powojennej Polsce. W literaturze i sztuce miejsce naczelne zajął realizm socjalistyczny gloryfikujący kulturę robotniczą, uprzemysłowienie, i niewiele mający wspólnego z tradycyjnymi wartościami wiejskiej kultury ludowej. 


\section{Abstract}

\section{Bożena Karwowska}

UNIVERSITY OF BRITISH COLUMBIA, VANCOUVER

Peasant Culture in the Polish Press 1944-1948: Warszawa and Debates on Postwar Poland's Cultural Model

The article explores early attempts at creating a model of postwar Polish culture based on the values of folk culture. Seeing peasant literature and culture as a better alternative to a politically enforced model of culture of workers as leaders of the working class, journalists publishing in Warszawa made it difficult (if not impossible) to depict the realities of Polish villages during the German occupation, and especially to examine peasants' attitudes towards Jews hiding in villages and the surrounding areas.

\section{Keywords}

social and cultural press, culture in the Polish People's Republic, folk literature, working class, Warszawa 